\title{
Edward Janak Politics, Disability, and Education Reform in the South: The Work of John Eldred Swearingen
}

New York: Palgrave Macmillan, 2014. 259 pp.

\section{Kate Rousmaniere}

Miami University, Ohio

This biography of a major educational leader in the American South during the Progressive Era is an interesting read in a number of ways. Like many local and regional histories, John Eldred Swearingen's story as state superintendent in South Carolina in the early twentieth century offers a keyhole view into larger social and educational reform movements. Swearingen championed efforts to modernize and equalize education in a state still shaped by the racial and economic systems and traditions of the old South, and he did so by battling some of the most blatantly racist and classist political leaders of the day. When successful, Swearingen introduced great progressive advancements to South Carolina's public education system, including secondary school curricular, accreditation, and classification systems; compulsory education laws; vocational education; improved teacher pay; expanded state funding for public schools; and most notably, improved funding for the separate African American school system. Swearingen is an excellent model of local progressive politics at work in education, and this in and of itself is a good story.

Swearingen's story is notable in at least two other ways. First, he was the descendant of avowed racists, including his uncle, who was a powerful state and federal politician who he continued to admire and support throughout his own career. Swearingen's loyalty to old South racial dominance while simultaneously advocating for African American educational advancement is one of the more curious aspects of his life. Secondly, he was blind, the result of a childhood hunting accident. These two elements, race and disability, serve as common themes through the biography, and the author offers provocative suggestions about how to think through Swearingen's political and personal strategies. 
Janak argues that Swearingen attended to the educational advancement of minority groups - specifically African American children and the children of the rural, white working-class and cotton mill workers - in part because of his sensitivity to being excluded as a man with disabilities. This claim seems valid, but still unsettling, in that however judicious and fair he was as a man and an educational leader, Swearingen was rarely, if ever, an advocate for people with disabilities. Beyond his early years teaching at the school for the disabled that he himself attended, Swearingen seems to have paid no specific attention to education for the disabled, and indeed, he tended to dismiss his blindness and urged others with disabilities to overcome their limitations. Janak explains some of Swearingen's attitudes as a result of a culture of masculinity that shaped his self-definition as an independent and strong professional and father and not what he feared to be, a passive handicapped person. Masculinity works as a counter to disability in this analysis, and so it may have been for Swearingen and other men with disabilities in the past and present. But Janak would have been well served to offer a critique that contemporary disability activists might make of Swearingen's philosophy: that "overcoming" disability is in effect accepting a social world that denies the multiplicity of human forms. Ironically, Swearingen often seemed more committed to changing social attitudes and educational offerings for African American youth than for people with disabilities. The book title is thus somewhat misleading: that Swearingen was blind is significant, and Janak covers the ground of Swearingen's own education and professional and personal drive very thoroughly. To that extent, this is a good study of a man who was disabled, but it is less of a study of disability as a social problem.

Another challenge of the book is that while Janak rightly argues that a biographical subject cannot be understood outside of their historical context, the story sometimes veers too deeply into that context, such as in chapter 3, which studies the political careers of the bombastic governor, Coleman Blease, and Swearingen's uncle, Benjamin Tillman, and their impact on Swearingen's career. The author takes us so deeply into the weeds of local and state politics that Swearingen's story is often lost. Janak justifies this by arguing for his focus on Swearingen as a political actor, strategist, and leader who carefully manoeuvred his way through an intensely complicated political culture. The focus on that culture is not necessarily a bad thing, and all readers may be interested to delve deeper into the peculiarities of the American South, well introduced in the first chapter on South Carolina Reconstruction politics after the Civil War. And Swearingen's equally peculiar brand of progressive politics, which supported African American education while also heralding the racist culture of the South, offers a fascinating portrait of the dance between progressivism, populism, and racism that has so marked North American politics and culture in the modern era.

Add Swearingen's disability to the story, and the intersecting dynamics of progressivism, professionalism, racism, tradition, masculinity, and politics develops into a fascinating story - certainly unique and thought-provoking in any examination of educational leadership and reform. 